\section{Looking Through the Mirror: the pratice of techinical assistance to social movements in Brazil seen by uruguayan experience

\author{
João Paulo O. Huguenin
}

\section{João Paulo O. Huguenin}

Master in Urbanism; Professor of Architecture and Urbanism at UFG

- Regional Goiás; joao_huguenin@ufg.br

\begin{abstract}
The Uruguayan model of housing cooperatives emerged in the 1960 s from movements in civil society. This experience was adapted to Latin American realities and arrived in Brazil in the 1980 s, along with the redemocaratização process, which made the emergence of new actors on the political scene and reconfigured the action of housing movements, which besides claiming passed propose projects with popular participation. The success of the self-managed housing production depends on three factors: the government, responsible for housing policy for self-management, the organized population, which will manage the project, and technical advice, support of the whole process. In this article we seek to reflect on this third factor, that is, the possibilities and limits of performance of technical advisory services in the Brazilian context. To achieve this objective, the Uruguayan experience as a case control. The choice of this approach proves to be useful both to understand our reality, and to visualize other possibilities. The contexts of each country led to different forms of assimilation of housing self-management. While in Uruguay pilot experiences have resulted in a national law regulating the housing cooperatives in Brazil had experiences in several municipalities that until 2004 did not succeed in becoming a national policy. The exponent of these experiences is the FUNAPS-Comunitário, launched in 1992 by the City of São Paulo. However, using this case as an example reduces the issue and mutes other successful experiences. Therefore, we will use the Rio experience, which although small, has peculiarities, such as the adoption of collective ownership in some cooperatives.
\end{abstract}

Keywords: housing self-management, technical assistance, Latin American experiences.

\section{Resumo}

O modelo uruguaio de cooperativas habitacionais emergiu nos anos 1960 a partir de movimentações na sociedade civil. Essa ex- oão Paulo O. Huguenin. Looking Through the Mirror: the pratice of techinical assistance to social movements in Brazil seen by uruguayan 198-216, jan./oct. 2017

submission date: $16 / 10 / 2016$ acceptance date: $26 / 04 / 2017$ 
periência foi adaptada à realidades latino-americanas e chegou ao Brasil nos anos 1980, juntamente com o processo de redemocaratização, que fez emergir novos atores na cena política e reconfigurou a ação dos movimentos de moradia, que além de reivindicar passaram propor projetos com a participação popular. O êxito da produção habitacional autogestionária depende de três fatores: o poder público, responsável pela política habitacional para a autogestão, a população organizada, que irá gerir o projeto, e a assessoria técnica, suporte de todo o processo. Neste artigo buscaremos refletir sobre este terceiro fator, ou seja, as possibilidades e limites da atuação das assessorias técnicas no contexto brasileiro. Para isso, utilizaremos a experiência uruguaia como um caso de controle. A opção por essa abordagem se mostra útil tanto para compreendermos nossa realidade, assim como para visualizarmos outras possibilidades. Os contextos de cada país levou a diferentes formas de assimilação da autogestão habitacional. Enquanto no Uruguai experiências pilotos acarretaram em uma lei nacional regulamentando as cooperativas habitacionais, no Brasil tivemos experiências em diversos municípios que até 2004 não lograram em se converter numa política nacional. O expoente dessas experiências é o FUNAPS-Comunitário, lançado em 1992 pela Prefeitura de São Paulo. No entanto, a utilização desse caso como exemplar reduz a questão e silencia outras experiências exitosas. Por isto, utilizaremos a experiência carioca, que apesar de pequena, apresenta peculiaridades, como a adoção da propriedade coletiva em algumas cooperativas.

Palavras-chave: autogestão habitacional, assessoria técnica, experiências latino americanas.

\section{Resumen}

El modelo uruguaya de cooperativas de viviendas surgió en la década de 1960 a partir de los movimientos de la sociedad civil. Esta experiencia se ha adaptado a las realidades de América Latina y llegó a Brasil en la década de 1980, junto con el proceso redemocaratização, lo que hizo que la aparición de nuevos actores en el escenario político y reconfigurar la acción de los movimientos de vivienda, que además de proponer proyectos alegando pasado con la participación popular. El éxito de la producción de vivienda autogestionada depende de tres factores: el gobierno, responsables de la política de vivienda para la autogestión, la población organizada, que gestionará el proyecto, y la asesoría técnica, apoyo de todo el proceso. En este artículo se pretende reflexionar sobre este tercer factor, es decir, las posibilidades y los límites de rendimiento de los servicios de asesoramiento técnico en el contexto brasileño. Para lograr este objetivo, la experiencia uruguaya en su caso control. La elección de este enfoque ha demostrado ser útil tanto para entender nuestra realidad, y para visualizar otras posibilidades. Los contextos de cada país dieron lugar a diferentes formas de asimilación de auto-gestión de la vivienda. Mientras que en Uruguay experiencias piloto han dado lugar a una ley nacional que regula las cooperativas de viviendas en Brasil tenido experiencias en varios municipios que hasta 2004 no tuvo éxito en convertirse en una política nacional. El exponente de estas experiencias es la FUNAPS-Comunitário, lanzada en 1992 por la ciudad de Sao Paulo. Sin embargo, utilizando este caso como un ejemplo reduce la emisión y silencia otras experiencias exitosas. Por lo tanto, vamos a utilizar la experiencia de Río, que aunque pequeña, tiene peculiaridades, tales como la adopción de la propiedad colectiva en algunas cooperativas.

Palabras-clave: autogestión de la vivienda, asesoría técnica, experiencias de América Latina. 


\section{Introduction}

The Housing Cooperativism in Uruguay began in the mid-1960s, from the movements of their civil society and the construction of three pilot experiences (in Isla Mala, Fray Bentos and Salto), which, together with the organization of the Uruguayan Cooperative Center (UCC) as a nucleus of technical assistance, culminated in the approval of the National Housing Law.

The three factors found in the Uruguayan cooperativism genealogy still constitute essential factors for the success in the housing self-managed construction: the organized population, main responsible for the whole process, technical assistance, giving the necessary support for the members decision-making, and the public power, promoter of public policies that contemplate the housing self-management.

The Uruguayan experience proved to be adequate to be adapted to the realities and peculiarities in different Latin American countries, arriving in Brazil in the 1980s, moment when the country went through the redemocratization process. The Brazilian political reopening gave rise to new actors in the political scene, generating the reconfiguration of the housing struggle movements action repertoires, which, in addition to the demands for greater housing production, began to make a series of propositions that sought the projects self-manage from the effective population participation.

In this article we seek to think over this third factor, that means, the possibilities and limits of the technical assistance performance in the Brazilian context. For this, we will use the Uruguayan experience as a control case. The option for this approach is useful both for understanding our reality and for visualizing other possibilities.

We must remember, in advance, that the contexts of each country took to different ways of assimilation of what would be the housing self-management. While in the neighboring country some pilot experiences took to a national law regulating housing cooperatives, in Brazil, with its continental dimensions, we had a set of experiences on a local scale, in several counties, which until 2004 had not achieved a conversion on housing policy.

The most outstanding example of these experiences is the "FUNAPS-Comunitário" program, launched in 1992 by São Paulo Municipal Government, under Luiza Erundina's administration. Without diminishing 
its relevance, the use of this case as an example to understand self-management in Brazil, take us to a reductionism of this issue and does not allow us to verify other successful experiences that would give us important contributions to advance in this proposal. For this reason, we will study in the present article the Rio experience, which, despite its low expressiveness in quantitative terms, presents some peculiarities worthy of note, such as the adoption of collective ownership in some cooperatives.

The Bento Rubião Human Rights Center was responsible for encouraging various organized groups to establish themselves as housing cooperatives, offering, for that, technical assistance on legal, social, administrative, architectural and urban areas, in a similar way to the technical assistance institutes in Uruguay. In the absence of an adequate public policy, the institution together with the population, used the international cooperation to make projects economically viable. The aim was to sensitize the city government to create a policy able to solve this demand. As the municipal program was never carried out, the experiences - although constant - were punctual and did not generate the accumulation of new professionals to work in this area.

With the Workers' Party (PT) national government, the housing movements achieved in 2004 the first housing program that served the banner of self-management in housing production. Through several advances and setbacks in politics, there is the "Minha Casa Minha Vida - Entidades" Program, which allows organized groups to access public resources, although these resources represent a very small part of the government housing financing that favors large contractors.

The new dinamyc of technical assistance to the financing programs implied a greater demand for work and a "professionalization" of an activity that until few times ago was carried out almost informally. Parallel to this, the foreign institutions that supported the initiatives stopped contributing financially. As at the beginning the whole project stage was not paid for the financing, only in the contracting of the work, many workers spent long periods without receiving and even moved away from this activity.

Currently, like the Uruguayan law, the MCMV-Entidades Program provides its own items for the projects assistance. However, for being a housing financing program and not a policy, the assistance is seen as a simple service and not as one of the determining fac- 
tors in the success of self-management.

Thinking of other advances in urban social movements such as the creation of the Social Interest Housing National Fund and Federal Law 11.888 / 2008, we will seek to consider the possibilities of advancement in the provision of technical assistance to organized social movements.

\section{The Uruguayan bases}

The National Housing Law is placed as a state law, differing, therefore, from the specific laws and programs of a particular government. Its objective is to confront the housing issue through the creation of instruments that account for institutional, bureaucratic, financial and operational structures.

At the institutional and bureaucratic field we can mention that the law creates the Housing Department and the Five Year Housing Plan. The Housing Department is the department responsible for all the law provided policy implementation and, for that, it counts on competence and autonomy. The Five Year Housing Plan is an obligation to be fulfilled by each government in its first year of office, and should be "integrated into economic and social development plans, which will include, among other items: goals, resources and their distribution". (RAFFO, 2008, 17)

The existence of this institutional-bureaucratic framework does not prevent that the five-year plan has, in several times, become a mere legal imposition, where the outlined goals are replaced by the political desire of the governmental decisions.

At the financial field, we highlight the creation of the National Housing Fund, which is a fund that has resources for the housing projects realization. In each five-year plan the sources that will to compose the fund are defined. In the more than 40 years of the housing law existence and validity, the fund was the most shredded, especially in the 1990s neoliberal governments that withdrew important sources for their maintenance without replacing them with others. The investment withdrawing from the Wages Taxes, for example, is a clear ideological manifestation where the state stops participating of the financing and construction of housing for that the housing problem be solved individually and by the market.

Still, other National Housing Law provisions do guarantee the necessary subsidies to low-income coope- 
ratives and the offered loans to the cooperative return to the fund through a financial adjustment system that guarantees the fund sustainability and the cooperatives housing production policy continuity.

At the operational level, the Uruguayan housing law becomes to be the legal framework for the Technical Assistance Institutes, which brings together professionals from different areas in multidisciplinary teams responsible for the assistance on the design, construction, cooperative organization, management and education on the Popular housing theme.

\section{The technical assistance institutes}

The Technical Assistance Institutes had its first formation in 1965, even before the Housing National Law promulgation, with the foundation of the Uruguayan Cooperative Center. From its inception to the present days, the institutes have played an important and fundamental role in the cooperative movement, especially in mutual aid cooperatives.

The Technical Assistance Institutes are non-governmental and non-profit organizations constituted by interdisciplinary professionals teams, which aim to advise all demands presented by cooperative members in the constitution and construction process of their housing cooperatives. The Housing National Law establishes the obligation of all cooperatives to have assistance from one of the Technical Assistance Institutes.

The technical assistance institutes action field was also defined by the housing law, and should answer to cooperative education, legal, accounting, financial, economic, social, project and construction management issues. This law brings a great innovation by bringing professionals from many areas to work together.

Fynn (2008) understands that, at that time, the interdisciplinary teams formation was a huge challenge, not only because they were professionals with different backgrounds but, above all, because these professionals had different ideological orientations and theoretical frameworks.

The multidisciplinary approach, as a process of continuous construction, involves the interrelation of a precisely defined technical knowledge set, establishing objectives and elaborating work methodologies that enable an integral approach towards the target groups, considering the reality not as a set of parties but as a whole.(FYNN, 2008,p: 80)

Inside the development of housing cooperatives pro- 
cess in the neighboring country, the horizontality between cooperatives/cooperatives members and Assistances Institutes/technical stands out. Although this process occurs in a non-linearly way and according to the specific context of each social group, Fynn lists twelve technical assistance work stages, ranging from the group's initial meetings to the moment they are living together: 1) Study of the group; 2) Cooperative group typification; 3)Cooperative Statute and Internal Rules discussion and analysis; 4) Registration of the legal entity; 5) Cooperative organs constitution; 6) Land obtaining; 7) Study, analysis and approval of the housing draft; 8) Housing Project analysis and approval; 9) Pre-work: Work and functions of the Construction Committee regulation;10) Work: mutual assistance organization, time control and administrative-accounting management; 11) Neighborhood coexistence and integration; 12) Post work.

The technical assistance work in self-managed housing cooperatives requires the cooperated base participation or runs the risk of distorting this principle of organization. However, this participation should not be seen in a romanticized way, its degree of intensity is directly proportional to the group's cohesion and participation level. It is defined by the constant interrelation between the various commissions that was set up inside the cooperative and its corresponding professionals of the Institute of Technical Assistance and by the cooperative assembly final decision, the organization's highest authority.

The organization of each cooperative can vary according to their respective social realities. One factor in this constitution is the origin of the cooperative, which may be territorial or union-based. This origin and commitment degree with the collective sphere will influence which commissions will be created to account for the construction process. Usually, we find in the Uruguayan housing cooperatives the commissions of purchase, work, production and of fomentation and participation. The commissions, on the other hand, are directly linked to Directors Commission, but regardless of this, all the cooperatives are guided by the decisions of their cooperative assembly.

Assistance institutes also have differences in their organization, some of which are very small, composed almost exclusively by professionals who will work directly with families in all stages of the cooperative's development process; And other are larger and more structured, with teams constituted in departments that highlight a specific professional to accompany a work/ 
cooperative.

Another facility for carrying out technical assistance in Uruguayan housing public policy is the existence of the Housing Portfolio of Social Interest, maintained by the Ministry of Housing, Territorial Planning and Environment, makes annual public calls where housing cooperatives can submit proposals for the use of lands registered in the real estate portfolio.

The technical assistance services to housing cooperatives has a value defined by law, limiting to $7 \%$ of all the housing financing value. In specific cases, where complementary engineering projects have a greater complexity than current works, there may have an increase of $2 \%$, reaching $9 \%$ of the financing value.

\section{The self-management ways in Brazil}

In Brazil, a serie of local experiences that used the work force of the own families involved in the project began to occur in the late 1970s and early 1980s. At that moment, some technicians began to disseminate the Uruguayan experience as something that could be implemented In our country and the urban social movements start to raise the banner of self-management in their projects.

The "Vila Nova Cachoeirinha" project, in 1989, is considered a paradigmatic case in the self-managed housing introduction in Brazil by being the first to use these principles and yet by constituting the basis for the housing movement in São Paulo and its Technical assistance to articulate, in the context of the popular and progressive municipal government of Luiza Erundina, for a municipal public policy that responded to its demands.

According to Bonduki (1992), "incorporating almost ten years of concrete experiences in the development of projects and interventions, supported by the strength of the housing movements [...] and by the technical staff who joined the administration after having, for years, assistanced the movement," took shape and developed the program called "FUNAPS-Comunitário".

A major limitation found in the program idealized by São Paulo City is in the inexistence of the legal figure of the housing cooperative, similar to that of the neighboring country. In Brazil we do not legally have an institutionalization of the housing cooperative that accounts for the nuances that this form of housing 
holds, being regulated by the cooperatives general law (Law 5.764 of 1971).

Due to the difficulty of using this law, organized groups that use self-management in housing production have adopted the legal structure of associations. At the same time as this solution had the advantage of escaping from the complexity of a cooperative, the group organized as an association has a greater fragility, since there is no reciprocal obligation among members.

Besides that, the financing programs of the organized groups that São Paulo's social movements fought so hard to conquer do not allow collective ownership, and after the conclusion of the work, the units can be inserted into the real estate market without great difficulties.

\section{The Rio Context}

In Rio de Janeiro, the initiatives that begin to guide self-management housing come from two fronts. The first is related to the real and imperative need for shelter of some organized groups in the Ecclesial Base Communities (EBCs). The second comes from the technical assistance offered to the groups by the then Human Rights Defense Center Bento Rubião, who understood that housing cooperativism could be a way to meet the advisory groups demand.

Thus, both the technical assitance and the constituted groups began to seek references that could help to develop their experiences. A process of recognition and training was initiated at the Union of Housing Movements (UHM) in São Paulo, and the Uruguayan Federation of Housing for Mutual Assistance (UFHMA) in Montevideo. The Bento Rubião Foundation technical assistance began a dialogue with the Uruguayan Cooperative Center (UCC) and the Center for Popular Advice and Self-Management (CPASM), led by Uruguayan Leonardo Pessina in São Paulo City.

In addition, the Bento Rubião Foundation believed that the three groups to which they were advising in the mid-1990s (Shangri-la, Nova Pixuna and Colméia) could be pilot experiments capable of demonstrating the viability of this type of production, for it to be done a housing program at the municipal level.

However, the many articulations with Rio de Janeiro municipal government to make the housing cooperatives viable was not fruitive, so all experiences occurred without public funding and without the mu- 
nicipality participation, what generated a certain "informality" of these examples.

In the impossibility of municipal support, the institution began to seek financing from foreign institutions that could make feasible a fund to enable the project of these three groups. At the end of 1995, the German international cooperation agency Misereor, linked to the Catholic Church bishops, provided $\$ 70,000$ for the Revolving Fund, which was to be used for the construction of 82 housing units.

The idea of this Fund was that, with the payment of monthly fees by families who used their resources, new housing could be financed for new housing cooperatives that would arise. However, this return of the amount to the fund was slow and, therefore, did not allow a sufficient amount of money to enable a new cooperative in a short time.

The few experiments carried out in Rio de Janeiro, for not counting on public resources and because they were not part of a rigid financing program, allowed innovations for the adoption of collective property. The solution found by the legal advice of Bento Rubião Foundation was to register the enterprises as housing and mixed cooperatives. Thus, the lot and the built housing units property were considered the cooperative's social capital. As all the associates answer for the cooperative as owners, the houses ownership is collective.

Thus, it makes more sense to treat the the cooperative properties as a collective patrimony to be maintained by everyone, eliminating, or at least reducing, the idea of private individual property and particular interest.

The lack of a public policy for housing self-management destabilizes the tripod (public policy - social organization and technical assistance) of the self-management defended by Ronconi (1995), causing the other two points to become overburdened and even destabilized. More directly, the little resource obtained to the pilot experiments was responsible for a high work of the families involved in the process, who spent an average of 17 hours per week of the family nucleus to the construction.

The technical assistance, which was organized along the Uruguayan institutes lines, counted on the participation of architects, engineers, lawyers, accountants, social workers and social agents. The low resource for the projects led these professionals to dedicate them- 
selves in parallel to other works, causing the worker wearer and interruptions in the process follow-up.

The lack of public policy led, on the other hand, to a informalization of housing cooperatives process, even being legally constituted as legal entities. The design and construction process ended up happening without answering to the urban planning and building regulations, due to the high degree of bureaucratization of these actions, the lack of available technicians to do the work and to the obstruction of approval by some agencies and concessionaires.

Finally, we emphasize that the lack of a policy directed to this type of project made difficult the propagation of this way of constructing the house and the city. After the pilot experiences of the 1990s, two other cooperatives were built with money from the revolving fund, until in 2004 the Solidarity Credit Program was created.

\section{Federal programs for self-management}

From 2003, with the Workers Party arrival to the Federal Government, a series of advances were possible in the construction of public policies for the city, such as the creation of the Cities Ministry, the Campaign for Participative Director Plans, the establishment of a Cities Council, the achievement of City Conferences at municipal, state and federal levels, among other advances.

In the housing field, we can mention the creation of the Housing National Policy (HNP) of 2004 and then complemented by the Law $11.124 / 2005$ sanction, the first popular initiative law, after 13 years of proceedings in the National Congress, which instituted the Social Interest Housing National System (SIHNS), the Social Interest Housing National Fund (SIHNF) and the SIHNF Management Council.

The four national entities NUPH, NMHS, NCRA and PMC called for the formulation of a program that prioritized the Housing assistance to families with incomes lower than three minimum wages and that was supported by the bases of cooperativism and associativism with the purpose of strengthening self-managed practices and popular organization. Responding to the movement expectations, justified by the concrete possibility of implementing in practice the proposals that for years - at least at the federal level - represented only the popular movement struggle flag (among them, the self-management in housing production). Solidary Credit Program was created in 2004. 
The experience absent of both the social movement and the technical assistance led to the Solidarity Credit Program complete failure in the Rio de Janeiro State. Only the Hope Cooperative project was hired and, even so, the impossibility of meeting the project's bureaucratic demands made its execution impossible.

In 2008, another social movements important achievement was the creation, in the federal government level, of the Social Interest Housing Program - Action to Support Housing Social Production, which operates with SIHNF resources. However, the two projects inscribed in the action - "Quilombo da Gamboa" and "Ocupação de Guia de Pacobaíba" - were not carried forward due to the low resource provided per unit.

In a context of policy expansion, the housing movements present in the state expanded their actions and proposed, through an agreement with the Rio de Janeiro State Land and Cartography Institute (RJSLCI), to access resources from the TA-SIHNF. In this context, only three technical assistance nuclei were placed as possible to the movements: the Bento Rubião Foundation itself, the Chique da Silva Association and the Popular Assistance Nucleus (PAN).

The SIHNF Technical Assistance program was obtained in two modalities: Technical Assistance for Mobilization and Community Organization and Technical Assistance for Projects. The advisory of Mobilization and Community Organization projects occurred satisfactorily, despite delays in payment and low remuneration. The projects advisory was impaired due to the insufficient amount contributed and to the payment delays suffered, since the technical assistance centers did not have in their technical staff professionals able to develop complementary projects, thus the service began to be outsourced and the low value foreseen for each work made it impossible to hire specialized offices.

In 2009, in a run-up to all the advances made, the Federal Government launches the "Minha Casa Minha Vida" Program and dismantles all the built housing policy. To replace the Solidarity Credit, a line of the new program, "Minha Casa Minha Vida - Entidades", was opened for social movements.

Despite this regression in housing policy, "Minha Casa Minha Vida - Entidades" is, until now, shown as the only possibility for the movements to carry out their actions with a view to housing production. In this sense, Hope Cooperative - which was not able to 
fit into the Solidary Credit Program - migrated to the MCMV-Entidades and built houses for 70 families. In addition to Hope Cooperative, there is a number of contracted projects and in the process of contracting with Caixa Econômica Federal Bank

\section{Contemporary approaches between Brazil and Uruguay}

Afim de comparar as experiências nos dois países, elegemos alguns pontos de aproximação e distanciamento entre as realidades de Brasil e Uruguai, no sentido de apontar caminhos para o avanço de uma política habitacional para a autogestão em nosso país.

\section{Conquista do território}

In order to compare the experiences in both countries, we chose some approach and distance points between the Brazil and Uruguay realities, to point out ways to advance a housing policy for self-management in our country.

\section{Territory conquest}

While Uruguay presents an efficient public policy in the territorial distribution, Brazil encourages the resolution of land provision by means of market, even though it presents a juridical-legal framework that gives conditions to face the real estate speculation and that guarantees the property social function fulfillment.

The Housing Portfolio of Social Interest, maintained by the Ministry of Housing, Territorial Planning and Environment, makes annual public calls where housing cooperatives can submit proposals for the use of lands registered in the real estate portfolio.

These proposals are evaluated according to criteria that take into account, in addition to the number of units and to the cooperative regularity, the cooperative social dynamics, favoring the group stability, the carried out activities in the pre-work stage and the social standard heterogeneity.

The "Minha Casa Minha Vida" program financing - which is a financing policy, more than a housing policy requires each association to search its ground in the market, with the possibilitie of taking up to $15 \%$ of the resource value in that purchase. The land dispute with the large construction companies causes the technical 
assistance to start before the project contracting stage, still in the lands' viability study. This fundamental work, which is sometimes redone, often becomes to unpaid or poorly paid work.

\section{Technical Assistance}

In Uruguay, the Housing National Law recognizes and regulates technical assistance institutes as key elements in the country's housing policy. Technical assistance is seen as a unique object, involving several areas of knowledge, from architecture, administration, accounting and advocacy, and especially, being accompanied by a social technician. As we have already explained, the technical assistance payment is limited to $7 \%$ of the project value

Within the MCMV-Entidades normative, the technical assistance is seen as a simple service provision between professionals/companies to the organized groups. The organizing entity can hire a single assistance to develop the entire project or hire the project by disciplines/stages.

Two points seem neuralgic within the program. The first is that the Social Work and the Technical Assistance are specific headings inside the program, implying that the project and social work do not necessarily have relations and implications of one to another such as the execution of Social Work, for which a caption of $2 \%$ of the enterprise value is foreseen.

The second point concerns the estimated value for the projects realization (architectural, urban and complementary), which provides different values for different enterprises sizes. Projects with up to 100 housing units count with investments of up to $3 \%$ of the value of the investment, projects with more than 100 and less than 300 housing units have their project value limited to $2 \%$, and projects with more than 300 units count with $1,5 \%$ of the project value.

This proportionality ends up not valuing the development and elaboration of the projects in a unique way for each cooperative. Besides the values are insufficient in some cases, in the large sets, the repetition of a single project is stimulated, since this values reduction is only possible with the solutions standardization.

\section{Population participation in projects}

In both countries we found that the methodology of participation in the architectural project decisions var- 
ies greatly in each technical assistance institute. Participation can be broad, with the stakeholders acting in the various stages of the process, or it may be more limited, of an advisory nature, where the assistance presents some project possibilities to be elected.

The Uruguay population participation is analyzed from the viewpoint of its participants as full, since all decisions must be approved by the Cooperative Assembly. However, the assembly is limited to the proposals approval or not, leaving little space for the members inventiveness. In addition, participation is also seen as the joint effort realization by the cooperative families, providing 21 hours of work per week in the construction of the cooperative - a number of hours that is very high and tiring for the cooperative.

In the national context, some technical assistance services, especially the Work Center for the Inhabited Environment Plant, have invested in the participatory project methodologies development. In addition, social movements began to raise the flag "more self-management and less "mutirão" (self-help)", thus advocating the reduction of manual labor in construction by Management administration, such as the activities of purchasing materials, hiring labor, work fronts decisions and deadlines, which has reduced the wear and tear of those involved.

\section{Architectural Space Conformation}

Every housing cooperative is concretized through an architectural object. Although the spatial issue is taken as secondary in the housing social production, architecture can be seen as a way of seeing the world, questioning it and seeking answers. We consider that the proposition of quality and stimulating environments, with public and private definition, is part of the constituting a housing cooperative challenge.

The Uruguayan experience shows us how, through the built environment, is it possible to express desires for a differentiated way of life. We believe that the good architectural quality of the initial experiences has helped to spread the successful public policy image. The twinned duplexes with exposed brick are a cooperative housing production hallmark in that country.

In Brazil, the pioneering experiences pursued the built environment quality. Currently, the state of São Paulo, where there was a local program in the 1990s, concentrates the highest quality architectural production. The backing of the "FUNAPS - Comunitário" housing program led to the emergence of a large number of 
technical assistance institutes devoted almost exclusively to working with social movements.

In other parts of the country this is not repeated, but there are a few exceptions. The large production volume of the "Minha Casa Minha Vida - Entidades" Program has shown a reproduction of the popular housing market standard with minimal areas, excessive standardization and the conformation of monotonous environments.

Another issue involving architecture and housing cooperatives is the construction of a city. Rather than securing decent housing for cooperative members, self-managed projects must be concerned with building living and thriving neighborhoods.

Currently in Uruguay, observing the attempt to control this production of the urban environment, the cooperatives are limited to the maximum number of fifty cooperative members, that means, fifty housing units. This limitation tends to escape of the large housing estates problems and seeks to prevent the standardization of the neighborhood. However, there is nothing to prevent different cooperatives from being built next to each other, and in case of peripheral location, this configuration can generate urban problems.

The experience of the large cooperative housing complexes in Uruguay in the 1970 s and 1980s shows how successfully an experience can be. With the several cooperatives grouping and with the public power concern, there are some cases in which the housing estates have commercial, leisure and cultural areas, and health and education equipment, such as Mesa 1 and José Pedro Varela housing estates.

In Brazil, currently, the units limit in a self-managed project is five hundred. However, the construction of large housing estates has not being accompanied by the infrastructure and equipment needed to guarantee the right to the city.

The cooperative size should be analyzed according to the place where it will be inserted and to the residents wishes, through the technical assistance institutes proposal. The families participation in the project decision-making process is one of the ways to build more lively and dynamic neighborhoods.

\section{Final Words}

For us, housing self-management must be firstly seen as a way of guaranteeing the right to housing, enshrined in the Universal Declaration of Human Rights 
and in our 1988 Constitution. At a time when rights have been violated and our laws are used to serving a group to the detriment of the collective well, to defend our victories and achievements is necessary. Secondly, housing self-management should be seen as a practice that points to other paths and ways of life. For this, it is fundamental to produce the house and the city for its use value, demercanizing, in what it is possible, these constructions.

Recalling Lefebvre (1999), "Change Life! Change society! They are senseless precepts without the production of an appropriate space. " (Lefebvre, 1991, 59) In this sense, we point out the importance of thinking about the power of this space and how architecture, along with several other factors, is important in the creation of this differential space. That is where the work of technical assistance in architecture and urbanism is indispensable.

When looking at housing production by self-management in Brazil, we find that it has not presented the quality it should, both because the groups organization processes have problems, as well as the fact of having an inefficient public policy and also for lack of technical assistance. In an attempt to look at possibilities of changing this situation, it was necessary to seek the origins of self-management housing in our country, inspired by the Uruguayan experience.

When we observe the neighboring country, we first find that in Brazil there is no housing policy that belongs to the nation, today we operate in gaps allowed by government programs, despite the fact that we have a series of laws that deal with the issue. With regard specifically to Technical Assistance in Architecture and Urbanism, we verified that our profession should approach those who need our work, in addition to being more open to collective constructions along with other professions. 


\section{References}

BONDUKI, N. Habitação e Autogestão: construindo territórios de utopia. Rio de Janeiro: Fase, 1992.

FYNN, C. El assessoriamento técnico. In: Nahoum, B. (org). Una historia con quince mil protagonistas. Montevidéu: Intendencia Municipal de Montevidéo, 2008.

GUILARD,F.;HUGUENIN,J.P.O. Algumas aproximações acerca da difusão e recepção do modelo uruguaio de produção cooperativa de moradia no contexto brasileiro. In: Anais do Seminario de Investigación Movimientos Sociales en movimiento. Montividéu: UdelaR, 2015.

HUGUENIN,J.P.O. O Território do Homem Comum: Constituição e Apropriação Cotidiana do Espaço em Cooperativas Habitacionais. Rio de Janeiro: Letra Capital, 2013.

KRUK, W. Ayuda Mutua y Tecnologia. In: Nahoum, B. (org). Una historia con quince mil protagonistas. Montevidéu: Intendencia Municipal de Montevidéo, 2008.

LEFEBFRE,H. The Production of Space. Oxford: Blackwell, 1991.

NAHOUM,B. La Ley de Vivienda, cuarenta años después. Solo se trata de aplicarla. In: Revista de Vivienda Popular, no 17. Montevidéu: UdelaR, 2008.

RAFFO,A.Cuarenta años después, en la busqueda de vivienda digna para todos. In: Revista de Vivienda Popular, no 17. Montevidéu: UdelaR, 2008.

RONCONI, R. Habitações construídas com gerenciamento pelos usuários com organização da força de trabalho em regime de mutirão: o programa FUNAPS Comunitário. São Carlos: EESC-USP, 1995. (diss.mestrado) 